\title{
АНТИЧНІ МОТИВИ В МОДІ ТА ДИЗАЙНІ ОДЯГУ КІНЦЯ ХХ - ПОЧАТКУ ХХІ СТ.
}

\section{Білякович Л. М.}

\section{ВСТУП}

Творче переосмислення історичних художніх стилів і сучасного їм костюма - невід'ємний складник моди і дизайну одягу XIX - початку XXI ст. Провідною функцією дизайнерських ретроспекцій є інновація через традицію, пошук за посередництвом інтерпретації минулого нової образно-пластичної виразності й нових дизайнерських парадигм.

Наскрізна в моді й дизайні одягу актуалізація історичних джерел у 1980-2010-х рр. набула нових характерних ознак і консолідувалася в самобутнє, яскраве явище - постмодерністський еклектичний дизайнiсторизм ${ }^{1}$. Однією 3 домінант історичних дизайнерських пошуків стало створення «художньо-проектної моделі античності» на основі давньогрецьких і давньоримських костюмів, архітектури, скульптури, монументального живопису, декоративно-ужиткового мистецтва в розмаї їх форм.

Значною мірою звернення до античної спадщини зумовлювалося перехідністю культури зламу ХX-XXI ст., кризою ii ідентичності, зустріччю «різноманітних інтенцій, явищ, процесів <..>, результатом якої $\epsilon$ досвід оновлення, розвитку чи загибелі» ${ }^{2}$. Інтерес сучасних дизайнерів до давньогрецького й давньоримського костюмів підживлювався сприйняттям античності як утраченої гармонії, осередку цінностей, покладених в основу європейської цивілізації, довершеної пластичної системи, відкритої до нових прочитань.

3 огляду на те що останніми десятиліттями ретроспекції античного костюма стали одним із найбільш значущих i художньо виразних векторів розвитку дизайну одягу, парадоксальним видається те, що в наявних наукових студіях вони не отримали вичерпного висвітлення, розглядалися побіжно або ж у річищі ширших питань.

Так, оглядово в контексті історії моди й пошукових стратегій Будинків мод античні інспірації творчості провідних дизайнерів охарактеризовано в працях Ш. Зеллінг (1999) $)^{3}$, Т. Козлової (2003)

\footnotetext{
${ }^{1}$ Галудзіна-Горобець В.І. Історизм у дизайні одягу другої половини XX - початку XXI ст.: генеза, динаміка, стильові особливості : дис. ... канд. мистецтвознавства : 17.00 .07 «Дизайн». Київ : Київський національний університет культури і мистецтв, 2019. С. 5.

2 Летина Н.Н. Рубежи - специфический код массовой культуры. Koдbl мaсcoвой культуры: российский дискурс : коллективная монография / под науч. ред. Т.С. Злотниковой, Т.И. Ерохиной. Ярославль : РИО ЯГПУ 2015. С. 97.

3 Зеллинг Ш. Мода. Век модельеров 1900-1999. Koln : Konemann, 1999. 658 с.
} 
О. Косарєвої (2006) $)^{5}$, О. Шевнюк (2008) 6 . У статті С. Бушуєвої «Класичні мотиви в моді XX-XXI ст.» (2013) творчі інтерпретації античного костюма проаналізовано на матеріалі доробку М. Фортюні, П. Пуаре, M. Вiонне $^{7}$, а розгляд сучасних тенденцій обмежено згадкою про античні ремінісценції в колекціях 2002-2004-х, 2007-2008-х pp. У статті М. Чебана «Античні мотиви в сучасному чоловічому одязі» (2017) досліджено конструктивні, формотворчі, декоративні особливості чоловічого античного вбрання та констатовано його творчу інтерпретацію в колекції Dolce\&Gabbana весна/літо 2013 p. ${ }^{8}$. У предметно-методологічній площині теорії та історії культури еволюцію античної стилістики в європейському одязі проаналізовано в дисертації О. Грантовської (2011) 9 .

Теоретико-методологічне підгрунтя пропонованого дослідження утворили праці вітчизняних i зарубіжних науковців, присвячені загальнотеоретичним аспектам історизму та зверненням до костюмів різних епох у дизайні одягу другої половини XX - початку XXI ст. (Л. Білякович $^{10}$, О. Воронцової ${ }^{11}$, С. Ванькович ${ }^{12}$, В. Галудзіної-

\footnotetext{
${ }^{4}$ Козлова Т. Стиль в костюме ХХ века. Москва : МГТУ им. А.И. Косыгина, 2003. 160 с.

${ }^{5}$ Косарева Е.А. Мода. XX век. Развитие модных форм костюма. Санкт-Петербург : Петербургский институт печати, 2006. 468 с.

${ }^{6}$ Шевнюк О.Л. Історія костюма : навчальний посібник. Київ : Знання, 2008. 375 с.

${ }^{7}$ Бушуева С.С. Классические мотивы в моде XX-XXI веков. Технико-технологические проблемы сервиса / гл. ред. д. т. н., проф. Г.В. Лепеш. Вып. 1. Санкт-Петербург, 2013. С. 121-126.

8 Чебан M.М. Античні мотиви в сучасному чоловічому одязі. Стан та перспективи розвитку культурологічної науки в Украӥні : збірник тез доповідей III Всеукр. наук.-практ. конф. / редкол. Н.В. Федотова (гол. ред.) та ін. Миколаїв : МФ КНУКіМ, 2017. Ч. 2. С. 126.

${ }^{9}$ Грантовська О.А. Еволюція античної стилістики в європейському одязі : автореф. дис. .... канд. мистецтвознавства : 26.00.01 «Теорія та історія культури» / Київський національний університет культури і мистецтв. Київ : КНУКіМ, 2011. 245 с.

10 Білякович Л. Темпоральність у структурі модних трендів: сутність, динаміка, прогнозування. Вісник Львівської національної академії мистецтв. Львів : Львівська національна академія мистецтв, 2018. Вип. 36. С. 207-222. Білякович Л.М. Барокова стилістика французького костюма як парадигма європейської моди XVII-XVIII ст. Украӥнська культура: минуле, сучасне, иляхи розвитку : збірник наукових праць ; Наукові записки Рівненського державного гуманітарного університету : у 2 т. / гол. ред. канд. пед. наук, проф. В.Г. Виткалов. Вип. 16. Рівне : Рівненський державний гуманітарний університет, 2010. Т. ІІ. С. 13-16; Білякович Л. Вплив західноєвропейських барокових тенденцій на формування української моди XVII-XVIII століття. Украӥнське мистецтвознавство: матеріали, дослідження, рещензї : збірник наукових праць / гол. ред. акад. НАН України, докт. іст. наук, проф. Г. Скрипник. Вип. 9. Київ : ІМФЕ ім. М.Т. Рильського НАН України, 2008. С. 286-293; Білякович Л.М. Класичні та сучасні наукові теорії художнього стилю бароко. Украӥнська культура XXI cm.: стан, проблеми, тендениії : матеріали Всеукраїнської науково-теоретичної конференції (м. Київ, 22 грудня 2010 року). Київ : Видавничий центр КНУКіМ, 2010. Ч. І. С. 7-10.

11 Білякович Л.М., Воронцова О.М. Мода епохи італійського Відродження: морфологічні особливості костюма. VII Культурологічні читання пам'яті Володимира Подкопаєва. Культурна трансформація сучасного украӥнського суспільства : збірник матер. Всеукраїнської наук.-практ. конф., Київ, 4-5 червня 2009 р. Київ : ДАКККіМ, 2009. Ч. 1. С. 98-105; Білякович Л.М., Воронцова О.М. Морфологічні особливості костюма італійського Відродження. Вісник Державноі академії керівних кадрів культури і мистеитва : щоквартальний наук. журнал / гол. ред. докт. мист., проф. В.Д. Шульгіна. 2009. № 8. Київ : Державна академія керівних кадрів культури і мистецтва, 2009. С. 84-88; Воронцова О.М. Італійський світський костюм XV-XVI ст. та його вплив на дизайн сучасного одягу : дис. ... канд. мистецтвознавства : 17.00.07 «Дизайн» / Київ. нац. ун-т культури i мистецтв. Київ : КНУКіМ, 2014. 219 с.

12 Ванькович С.М. Прообразы современной моды в аспекте общехудожественных тенденций прошлых епох. Мода и дизайн: исторический опыт новые технологии : спец. вып. Вестника СПГУТД. Санкт-Петербург : СПГУТД, 2004. С. 112-123.
} 
Горобець $^{13}$, А. Демшиної ${ }^{14}$, Т. Кротової ${ }^{15}$, О. Москвина $\left.{ }^{16}\right)$. Грунтовний аналіз дизайн-історизму як послідовної актуалізації множинних художніх стилів минулого й сучасного їм костюма з метою вирішення актуальних творчих завдань представлено в дисертації В. ГалудзіноїГоробець (2019) ${ }^{17}$, виконаній під керівництвом проф. Л. Білякович у межах наукових досліджень кафедри дизайну й технологій КНУКіМ.

Отже, стан дослідження питання обгрунтовує актуальність його подальших наукових студій 3 метою характеристики образних, формотворчих, декоративних особливостей інтерпретації античних мотивів на грунті естетики постмодернізму в дизайні одягу 1980-х 2010-x pp.

\section{1. Образно-пластичні особливості античного костюма та витоки його інтерпретацій у дизайні одягу XX ст.}

Античний костюм віддзеркалив властиве тогочасній культурі уявлення про світ як одухотворену природу-physis, упорядкований Космос, що поєднав етичні та естетичні характеристики, і людину як гармонійний духовно-тілесний мікрокосм. Відображенням античного світогляду в жіночому й чоловічому одязі стали симетрія, відповідність природним членуванням тіла, пропорційність частин і цілого, відчуття міри, раціональність, домінування вертикалей та опорні горизонтальні лінії. Вагома роль в образно-пластичному вирішенні давньогрецького та давньоримського костюмів належала драпіруванням, що створювали виважений чіткий ритм.

\footnotetext{
${ }^{13}$ Галудзіна-Горобець В.I. Історизм у дизайні одягу другої половини XX - початку XXI ст.: теоретико-методологічний аспект. Вісник Львівської національної академії мистецтв. 2018. Вип. 38. Львів : Львівська національна академія мистецтв, 2018. С. 93-111.

14 Демшина А.Ю. Ретроспективизм в современной моде как симптом динамики образов. Tpydbl Санкт-Петербургского гос. ин-та культуры / ред. колл. А.Ю. Русаков (отв. ред.), Т.В. Захарчук (зам. отв. ред.), Л.Н. Кен, М.К. Лопачева, И.А. Свирская, С.А. Владимирова (отв. секретар). Вып. 1. Санкт-Петербург : СПбГУКИ, 2013. С. 9-17.

${ }_{15}$ Кротова Т.Ф. Класичний костюм в європейській моді XIX - початку XXI століття: еволюція форм і художньо-стильові особливості : автореф. дис. ... докт. мистецтвознавства : 17.00 .06 «Декоративне і прикладне мистецтво» / Львівська національна академія мистецтв. Львів : ЛНАМ, 2015. $31 \mathrm{c}$.

16 Москвин А.Ю. Исторический крой в современном проектировании: от реминисценции до реконструкции. Фундаментальные и прикладные исследования: проблемы и результаты : сборник материалов IX международной научно-практической конференции (16 декабря 2013 г., Новосибирск) / гл. ред. проф. О.К. Арутюнян. Новосибирск : ЦРНС, 2013. С. 168-172; Москвин А.Ю. Проектирование мужской одежды на основе ретроспективного системного анализа конструктивных решений : дисс. ... канд. техн. наук : 17.00.06 «Техническая эстетика и дизайн» / СанктПетербургский государственный университет технологии и дизайна. Санкт-Петербург : СПбГУТД, 2015. 239 с.; Москвин А.Ю. Ретроспективный анализ проявления исторических мотивов в модной форме костюма. Мир науки, культуры, образования / гл. ред. докт. пед. наук, проф. А.В. Петров. Горно-Алтайск : АтпГУ, 2014. № 2. С. 271-274; Москвин А.Ю. Элементы исторического кроя в современном художественном проектировании. Вестник молодых ученых Санкт-Петербургского государственного университета технологии и дизайна : в 3 вып. / С.-Петербургск. гос. ун-т технологии и дизайна ; гл. ред. проф. А.Г. Макаров. Санкт-Петербург : ФГБОУВПО «СПГУТД», 2012. Вып. 3 : Искусствоведение и дизайн. С. 62-65.

${ }_{17}$ Галудзіна-Горобець В.I. Історизм у дизайні одягу другої половини XX - початку XXI ст.: генеза, динаміка, стильові особливості : дис. ... канд. мистецтвознавства : 17.00 .07 «изайн». Київ : Київський національний університет культури і мистецтв, 2019. 242 с.
} 
Нижнім одягом у Стародавній Греції в різні періоди слугував хітон прямокутний клапоть тканини, складений уздовж лівого боку, закріплений фібулами, підперезаний паском із напуском (колпосом), із вільно спадаючими бганками. Жінки носили довгий хітон, який уподібнював постать колоні з вертикалями канелюр. Чоловічий хітон сягав колін, хітон старійшин, державних діячів, учасників ритуальних дій - щиколоток. Доричний хітон підперізували на талії, іонічний - на талії, стегнах, хрест-навхрест на грудях. Різновидом хітону був пеплос із незшитим правим боком. Іноді доричний хітон утворював горизонтальні складки на плечовому поясі - диплодій, які пластично урізноманітнювали вбрання. На хітон надягали плащ - гіматій із прямокутного відрізу вовняної тканини, накинутої на ліве плече зі спини так, аби вона закривала ліву руку й спадала вниз на 1/3 своєї довжини. Залишок тканини пропускали під правою рукою, прикриваючи тіло спереду, а кінець закидали назад через ліве плече.

Одяг відшивали 3 льону, тонкої вовни, суміші льону 3 вовною. Найбільш вишуканим кольором жіночого та чоловічого хітонів уважався білий. Тонку природну гаму створювали блакитний, світло-рожевий, бузковий, жовтий кольори. Вбрання декорували орнаментальними смугами: меандру, крітських хвиль, стилізованих рослин.

Взуття греків було шкіряним, з ремінцями-смужками. У святковому варіанті - насичених яскравих кольорів, із золотим чи срібним декором. На щодень надягали сандалії. Популярними були низькі м'які чобіткиперсикаї й високі ремінчасті - ендроміс. Костюм доповнювали пряжками, фібулами, діадемами, пасками.

Римський костюм нагадував грецький, однак набув більш урочистих, святкових форм. Основу жіночого вбрання утворювала туніка-інтима, верхню частину - стола чи пала, кінець якої накидали на голову. Чоловічий костюм у період Республіки складався з лляної туніки й вовняної тоги. Початково тогу виконували 3 прямокутного клаптя тканини, на зразок грецького гіматія, а туніка (колобіум), модифікація грецького хітону, сягала колін. Із часом тога набула еліпсоподібної форми, що урізноманітнило способи драпірувань. Кінець тоги перекидали через ліву руку. Вищі соціальні верстви носили тунікуталаріс із довгими вузькими рукавами. Знаком воїнської гідності слугувала туніка, декорована золотими пальмовими гілками, i пурпурний плащ - полудаментум. У пізньому Римі тогу змінив далматик - довге, прилягаюче вбрання із цільнокроєними рукавами. На зміну туніці прийшла пенула - кроєна по косій накидка 3 прорізом для голови. Основними кольорами давньоримського костюма були білий, жовтий, вохристий, коричневий. Шляхетне походження й високий соціальний статус маркував пурпур. Матеріалами костюма слугували 
льон, вовна, згодом укритий великими візерунками щільний чи прозорий східний шовк.

У ті чи інші періоди історії моди й дизайну одягу джерелами творчих інтерпретацій слугували різні аспекти античного костюма: його крій, форма, силует, пропорції, прийоми драпірувань. Увагу дизайнерів привернули гладкі, однотонні вовняні, лляні, шовково-лляні фактури, що утворювали гру великих площин; поєднання білої та інших природних барв. Предметом творчих тлумачень слугували форми античної архітектури (волюти, канелюри, профільовані карнизи), і1і орнаментальні мотиви (меандр, ови, пальмети тощо), фрески, вазопис, скульптура. Дизайнерські образи доповнили античні зачіски, діадеми, браслети, пов’язки, ремінцеві сандалії, інші типи античного взуття.

Однією 3 перших актуалізацій пропорційності, гармонійності, раціональності давньогрецького й давньоримського вбрання став костюм доби Ренесансу, однак без наслідування античних конструктивних частин.

Раціональність, лаконізм античного костюма відродилися в тунікоподібних шміз неокласицизму, у яких давньогрецькому ідеалу природної гармонії суголосили невагомі білі муслін, батист, перкаль, газ, конструктивна простота, увиразнення форм жіночого тіла завдяки вертикальним драперіям i шалям, що нагадували гіматій. Цілісності образу сприяли діадеми, камеї, зачіски «грецький вузол», «а ля грек», «а ля Титус», «а ля Каракала», давньогрецькі орнаменти, сандалії, туфлі на пласкій підошві та способи репрезентації вбрання, зафіксовані в живописних портретах зламу XVIII-XIX ст. (Ж.Л. Давид «Портрет мадам Рекамьє», 1800; «Портрет Анріетти де Вернінак», 1798-1799; Ф. Жерар «Портрет мадам Рекамьє», 1805 та ін.).

Велич Стародавнього Риму відлунювала в сукнях стилю ампір (1804-1820), що зберегли конструктивні членування шміз та алюзії 3 античним хітоном, однак завдяки коштовності щільних тканин (шовку, оксамиту, газу на підкладці 3 парчі), золотому шитву, пайєткам, рукавам-ліхтарикам, глибокому вирізу на спині, насиченій гамі кольорів набули блиску, урочистості, пишноти, розкоші.

Нова хвиля інтересу до античного костюма, підживлювана археологічними відкриттями й науковим вивченням античної спадщини, припала на злам XIX-XX ст. Так, професором École des BeauX-Arts y Парижі Леоном Езеєм у фундаментальній праці «Історія античного костюма» (1922) реконструйовано та систематизовано різні типи античного вбрання на основі докладного аналізу вазопису, давньогрецької й давньоримської скульптури, археологічних джерел ${ }^{18}$.

\footnotetext{
${ }^{18}$ Бушуева С.С. Классические мотивы в моде XX-XXI веков. Технико-технологические проблемы сервиса / гл. ред. д. т. н., проф. Г.В. Лепеш. Вып. 1. Санкт-Петербург, 2013. С. 124.
} 
Актуалізація античних принципів формотворення простежується в сукнях Mariano Fortuny - 3 плісе, що імітує канелюри колон, акцентованим плечовим поясом, прямим кроєм (модель «Дельфос», 1907), шарфом «кносос» (1906). Стилізацією хітона 3 диплодієм стали скульптурно виразні туніки дизайнера 3 намистинами 3 венеціанського скла.

Популяризації античних мотивів у дизайні одягу початку XX ст. спричинився Paul Poiret - автор вишуканих суконь із прямим силуетом, вузькою спідницею та завищеною талією, відомих під назвою «Vague» («Хвиля»). Відзнакою колекцій дизайнера стало поєднання стилізацій хітону, туніки, кімоно. Античні ремінісценції та впливи ампіру притаманні моделях Будинку мод Раquin.

Античний ідеал природності й гармонії віддзеркалив у моделях Madeleine Vionnet - прямих, із невеликим цільнокроєним рукавом, ледь заниженою талією, золотавим графічним декором за мотивами давньогрецького вазопису. Зв'язок творчості дизайнера 3 античним костюмом унаочнили однотонні світлі тканини, моделювання за допомогою наколок, м'які драперії, чіткий ритм. Античний колорит колекцій Madeleine Vionnet увиразнили світлини Гойнієн-Гюне 1931 р., на якій модель у розвіяній вітром білій, рясно драпірованій сукні уподібнено статуї Ніке з акрополя Афін. Сформований дизайнером ідеал позначився на практиці Голівуду, екранних образах Джин Харлоу, Джоан Кроуфорд, Грети Гарбо.

Інтерес до давньогрецького хітону простежується у створених методом моделювання на фігурі, майстерно драпірованих білих сукнях Madame Gres (Germaine Emilie Krebs).

Спорадичні повернення до античних мотивів характерні для стилю «New look», зокрема сукні Christian Dior «Венера» з колекції осінь/зима 1949-1950 рр., із хвилями сріблясто-білої шовкової органзи, уподібненої мушлям і морській піні, з якої народилася богиня кохання й краси.

На тлі утвердження полістилізму й демократизації моди, прагнення до відродження античного ідеалу стилізація форм і силуету античного костюма простежуються в моделях Roy Halston 1970-х рр.: вишукано лаконічних, 3 однотонних натуральних тканин, із ритмізованими драперіями, кроєм «на запах».

Отже, огляд історії моди й дизайну одягу засвідчує різну міру інтенсивності та циклічність актуалізації античних мотивів: від консолідації в цілісне явище в неокласичному жіночому костюмі Директорії та стилю ампір до авторського осмислення у творчості окремих провідних дизайнерів першої половини XX ст. до редукції на тлі мінімалізму 1960-х і полістилізму 1970-1980-х рр. 


\section{2. Образні, формотворчі, декоративні особливості інтерпретації античних мотивів на грунті естетики постмодернізму в дизайні одягу 1980-х - 2010-х рр.}

Аналіз колекцій провідних світових дизайнерів засвідчує, що інтерпретація античних мотивів у дизайні одягу кінця XX - початку XXI ст. зумовлювалася дуальною природою постмодернізму 3 його «тугою за історією», естетичним ставленням до неї, інтересом до гуманістичного потенціалу традицій та ігровою, іронічною інтерпретацією культурних форм ${ }^{19}$.

У першому 3 означених аспектів звернення до античності в іiі природності, гармонії, єдності людини й усесвіту виявилося у створенні цілісних дизайнерських образів тих чи інших періодів античної історії, співмірності, монументальності, довершеній простоті ліній і костюмних форм. У другому - у новій контекстуалізації античних елементів, грі художніми кодами, трансформації й деконструкції античного вбрання.

Одним із найбільш яскравих зразків сучасної репрезентації античного естетичного ідеалу стала колекція Christian Dior by Ferré haute couture spring/summer 1992 з «подвійним посиланням» на форми давньогрецького хітону та іонічних і корінфських колон. Так, із давньогрецьким костюмом сукні споріднили чітка архітектоніка, силует, Т-подібний крій, співвідношення вертикалей i горизонталей, пропорції й загальне членування форм. Архітектурні витоки дизайнерського образу засвідчили пластичне вирішення плечового поясу та деталі декору, що нагадують капітелі й антаблементи античних споруд. Наприклад, в одній із кращих моделей показу, відомій під назвою Palladio dress (рис. 1), силует рукавівліхтариків уподібнено спіральним завитками під абакою корінфської капітелі, а мереживні листки - ï декоративному мотиву - аканту. Архітектурні асоціації посилює декор ліфу, утвореного горизонтальними смугами зі стилізованими кавликулами, каліксами, розетами, пальметами, овами. Структуроутворювального значення набувають ритмізовані прямокутники під ліфом, що нагадують пояс «сухариків» між архітравом і карнизом малоазійського варіанта іонійського ордеру. Важливим аспектом образного вирішення моделі $\epsilon$ відзначена Вітрувієм асоційованість іонічного та корінфського ордерів із жіночою і дівочою вишуканістю, м'якістю, емоційністю, стрункістю ${ }^{20}$.

Форми давньогрецької архітектури переосмислено в кроєній по косій біло-золотавій сукні з плечовим поясом у вигляді волют і декоромакантом. Відсилання до давньогрецького хітона помітне в пропорціях костюма з приталеною блузою та довгою спідницею з високим розрізом. Асоціації з давньогрецькою архітектурою викликає стрункий силует,

\footnotetext{
${ }^{19}$ Маньковская Н.Б. Эстетика постмодернизма. Санкт-Петербург : Алетейя, 2000. С. 11, 140-158.

${ }^{20}$ Витрувий. Десять книг об архитектуре. Москва : КомКнига, 2005. Кн. 4. С. 65-66.
} 
вертикальні смуги, що нагадують канелюри, плечовий пояс, схожий на архітрав з іоніками й листками аканту. Егейські та класичні мотиви зустрічаємо в білій довгій сукні Т-подібного силуету з акцентованим плечовим поясом, вертикальними смугами-канелюрами, золотим кольє і браслетом, гнучкі рослинні форми яких асоціюються з фресками Криту.

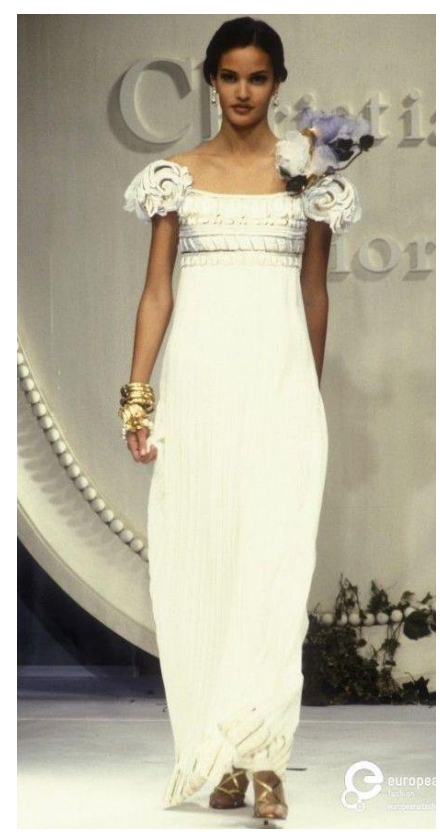

Pис. 1

Образній виразності колекції сприяє фактура натуральних тканин, схожих на давньогрецький тонкий льон і суміш льону 3 шовком. Асоціації 3 яскравим сонцем Еллади й світлоносністю пароського мармуру викликає поєднання біло-кремового тону виробів, золота декору та аксесуарів. Враження посилюють зачіски - «грецькі вузли», «каримбоси», «лампадіони», що увиразнюють силует голівки, шиї, плечей. Давньогрецький колорит відтворює золотаве смужкове взуття.

У колекції американського дизайнера Donna Caran prêt-à-porter весна/літо 2002 р. античний образ гармонії, простоти, єдності людини й природи відтворено завдяки стилізації короткого дівочого хітону для гімнастичних занять $з$ одним відкритим плечем. Вираженню авторської ідеї сприяють лаконізм силуетів і ліній, вільне драпірування, що підкреслює красу тіла, легкий шовк, білі, чорні, коралові кольори. Образ повітряної стихії, органічності й гармонії буття відтворює однотонна чи 3 ручними розписами невагома органза. Створенню урухомлених вільних об'ємів слугують експерименти 3 асиметричним швом. Складною асоціативністю позначено дизайнерське рішення довгої білої напівпрозорої трикотажної сукні, яка наче хвилями огортає тіло й формує образ народження Афродіти з водних стихій (рис. 2). 


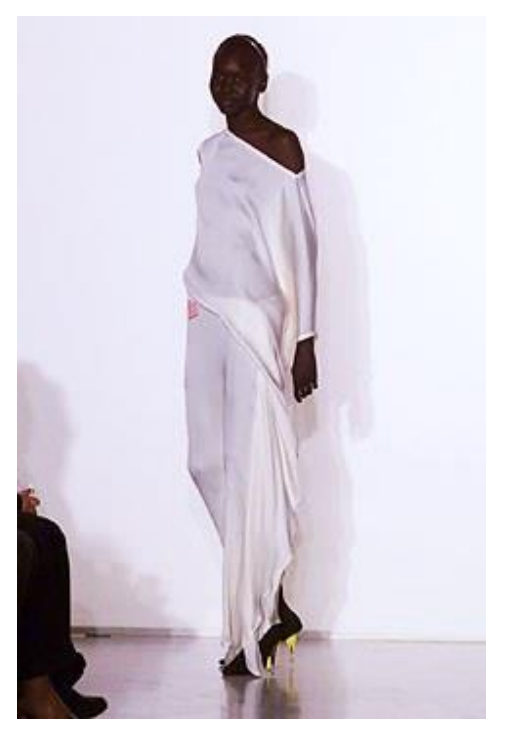

Pис. 2

У моделях колекції Donna Caran prêt-à-porter осінь/зима 2003-2004 pp. асоціації з античним жіночим вбранням викликають чіткі врівноважені силуети, лаконізм ліній, майстерне драпірування, що увиразнює красу тіла. Ремінісценцією античного вбрання сприймаються фібули на плечі, високі зачіски, ремінцеве взуття. Привабливості дизайнерським рішенням надає контраст мінімалізму образно-виражальних засобів і витонченої чуттєвості форм.

У колекції Donna Caran prêt-à-porter весна/літо 2004 р. античну гармонію людини і природи та стилістику жіночого хітону відтворено силуетом, пропорційно-конструктивними членуваннями, повітряною невагомістю шифону білого й золотавого кольорів. Засобом образнопластичної виразності слугує співвідношення одягу та досконалого, засмаглого тіла, що проглядає крізь напівпрозорі фактури або ж увиразнюється обрамленням тканин. У низці моделей високі бічні розрізи сприймаються стилізацією античного пеплосу. Істотним аспектом образів є актуалізація античного ідеалу калокагатії - єдності духовної й тілесної краси.

У колекції Alberta Feretti весна/літо 2008 р. мотиви хітону, пеплосу, гіматіону, столи інтегровано в лаконічне, витончене повсякденне жіноче вбрання. Особливостями дизайнерських рішень $є$ урівноваженість конструкцій, вільний крій, значна кількість драпірувань. 3 античним жіночим вбранням моделі споріднили прохолодні білі, оливкові, cipi, синьо-зелені, блакитні й теплі вохристі, персикові, бордові кольори, що нагадують «вицвілі кольори стародавніх храмів і фресок» ${ }^{21}$; гра невагомого шовку, шифону, тонкого трикотажу. Значущими в

\footnotetext{
${ }^{21}$ Alberta Feretti. Spring. Ready-to-wear. 2008. URL: https://www.vogue.com/fashion-shows/spring2008-ready-to-wear/alberta-ferretti.
} 
пластичному вирішенні виробів $є$ чіткі силуети i співвідношення великих однотонних площин (рис. 3). Виразності дизайнерським образам надають монохромні біло-сірі принти з відтворенням римського фризу і фрагментів давньогрецьких скульптур.

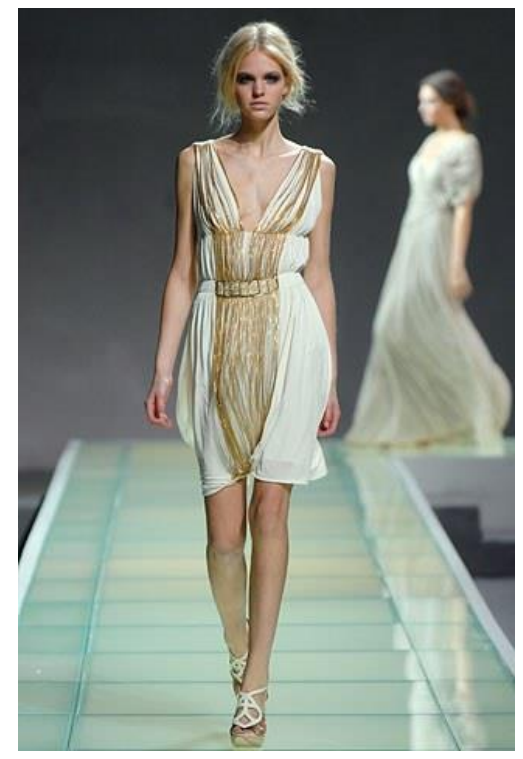

Pис. 3

Цілісний образ греко-римської античності створено в колекції Будинку мод Valentino haute couture осінь/зима 2014-2015 pp. дизайнерами Maria Grazia Chiuri й Pier Paolo Piccioli. Наскрізною темою колекції $\epsilon$ гармонійність людини як мікрокосму та іiі єдність із природою-physis, візуалізована в красі уподібнених мармуровим статуям жіночих тіл, оповитих багатошаровими повітряними драперіями прозорого шовку білих, кремових, золотавих, світло-сріблястих кольорів (рис. 4). Античними «маркерами» моделей слугують наслідування пропорцій хітона (рис. 5) і перехресні смуги шкіри й тканин. Асоціації 3 римською столою викликають оливкова, блакитна, чорно-біла асиметричні сукні, модельовані із цілісних відрізів тонкої вовни. Відзнакою моделей $\epsilon$ лаконізм виражальних засобів і створення асоціативного образу завдяки алюзіям із силуетом i пропорціям історичного вбрання. Особливістю дизайнерських рішень є досягнення пластичної виразності завдяки чіткому геометризованому силуету й грі великих однотонних площин. Велич і блиск Стародавнього Риму відтворено в золотавих прозорих сукнях із сітчастих тканин (рис. 6). Вагомого значення в колекції набувають вертикальні симетричні давньоримські орнаменти - золотаві, на чорному чи білому тлі. Античні асоціації викликають сандалії-гладіатори. Алюзією з образами міфічних істот сприймається пальто з чорних пір'їн. 


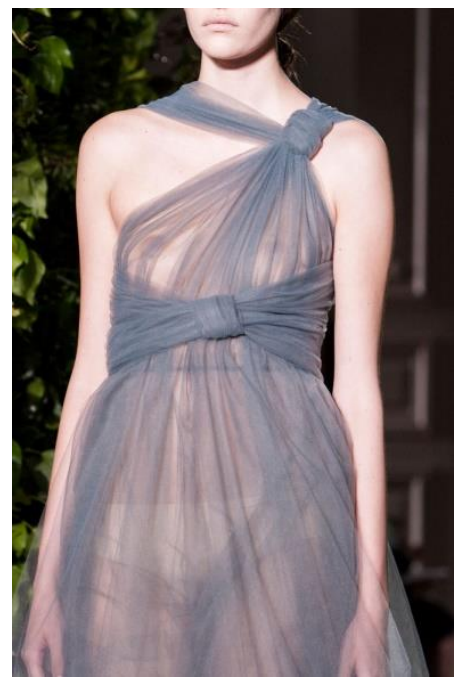

Puc. 4

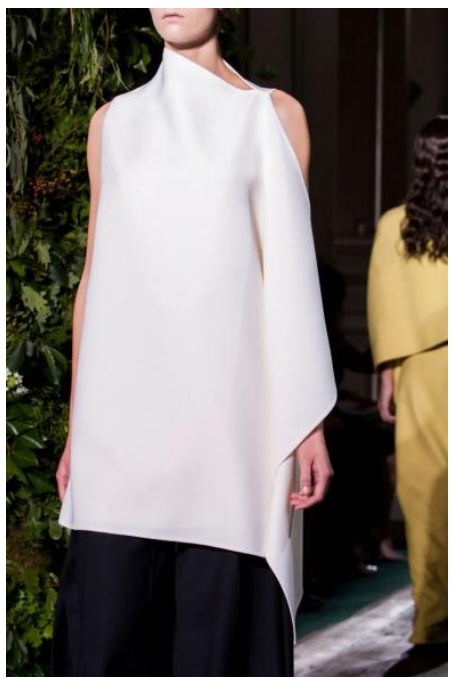

Рис. 5

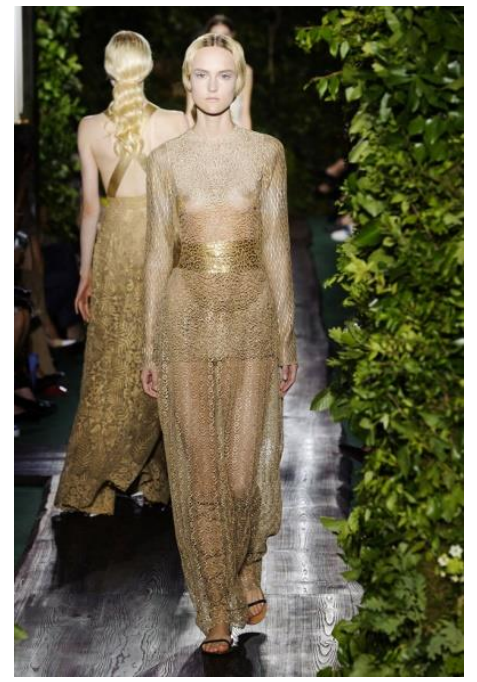

Рис. 6

Цілісний, романтичний, величний образ Стародавнього Риму створено в колекції Будинку мод Valentino haute couture осінь/зима 2014-2015 pp., продемонстрованій біля стін Колізею, на п'яца Міньянеллі в сутінках спекотного дня. Домінантним у колекції стало поєднання чорного і золота, що відобразило багатогранність Рима, за словами авторів колекції, «дещо зловісного, дещо нуар» ${ }^{22}$. Основними історичними прототипами моделей слугували туніка і стола 3 тонкої шерсті, оксамиту, напівпрозорих мереживних тканин. Багатогранності образам надала інтеграція в жіночий костюм мотивів чоловічої давньоримської тоги та золоті аксесуари роботи Алесандро Гаджіо - кольє, браслети, підвіски, діадеми, вінці. Упізнаваним античним маркером колекції стали смужкові сандалії. Створенню глорифікаційного образу сприяли золото й пурпур - символ імператорської величі, влади, слави, багатства (рис. 7). Вагомого значення набула стародавня символіка - стебла пшениці на золотій мереживній сукні, грифони на плащі. Однією 3 кращих моделей показу стала чорна напівпрозора довга сукня з орлом, символом імператорського Риму, з червоною стрічкою в дзьобі (рис. 8). Показове використання як джерела дизайнерського рішення фрескового зображення орла, віднайденого у 2014 р. під час реставрації однієї 3 римських будівель ${ }^{23}$.

Інший полюс інтерпретації античних мотивів у дизайні одягу кінця XX - початку XXI ст. утворили поєднання елементів історичного й сучасного костюмів, ігрова, іронічна постмодерністська трансформація античних форм.

\footnotetext{
${ }^{22}$ Phelps N. Valentino. Fall 2015. Couture. VOGUE. JULY 9, 2015. URL: https://www.vogue.com/ fashion-shows/fall-2015-couture/valentino.

${ }^{23}$ Phelps N. Valentino. Fall 2015. Couture. VOGUE. JULY 9, 2015. URL: https://www.vogue.com/ fashion-shows/fall-2015-couture/valentino.
} 


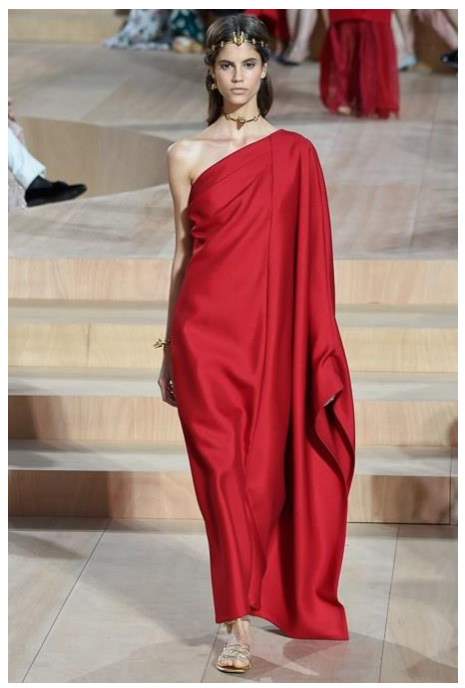

Puc. 7

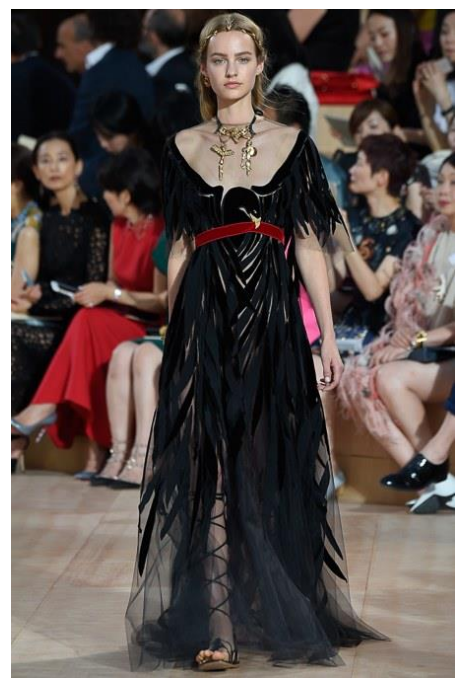

Puc. 8

Прикладом слугує колекція Gianni Versace haute couture весна/літо 1990 р., у якій орнаментальний мотив пальмети, поширений в античних антефіксах, карнизах, капітелях іонічних $\mathrm{i}$ корінфських колон, застосовано в яскраво-зеленому топі з бірюзовими короткими шортами. Не воднораз дизайнер звертався до давньогрецького мотиву меандру, контекстуалізуючи його в класичне чи гостро актуальне вбрання. Відзнакою колекцій Gianni Versace $є$ декоруванням меандром якоїсь однієї деталі: пілок жакета, кишені, взуття (колекція haute couture осінь/зима 1991-1992рр.). Семантично-образний контраст покладено в основу дизайнерського вирішення еротичної бірюзової сукні зі стразами i профільними портретами 3 античних камей (haute couture осінь/зима 1991-1992 pp.).

Постмодерністською іронією, грою, сміливою трансформацією та еклектичним поєднанням античних і сучасних форм позначено колекції Dolce\&Gabbana початку 2000-х pp. Так, хітону з колекції осінь/зима 2002-2003 pp. надано незвичних еротичних відтінків завдяки вкороченню й поєднанню 3 високим шкіряним взуттям. Істотним аспектом образу є асоційованість із давньогрецькою богинею полювання Артемідою й римською Діаною. Еротичні ноти відчутні в моделях колекції весна/літо 2003 р., у яких хітон трансформовано в блузу 3 відкритим плечем і поєднано з міні-спідницями, шортами, джинсами, туфлями й чоботами на високих підборах, гумовим взуттям, сучасними шкіряними пасками, позолоченими кольє з написами «LOVE», «SEX» (рис. 9). Чуттєвості образам надає яскраво-червоний колір. Постмодерністський еклектизм засвідчує поєднання блузи-хітона і смугастих «піратських» спідниць. У низці моделей постмодерністську дискретність світу відбито в хаотизації драперій, порушенні пропорцій хітона, руйнації форм. Проявом постмодерністського деконструктивізму $\epsilon$ 
поєднання в асиметричній конструкції форми хітона, коміра й рукава класичної блузи.

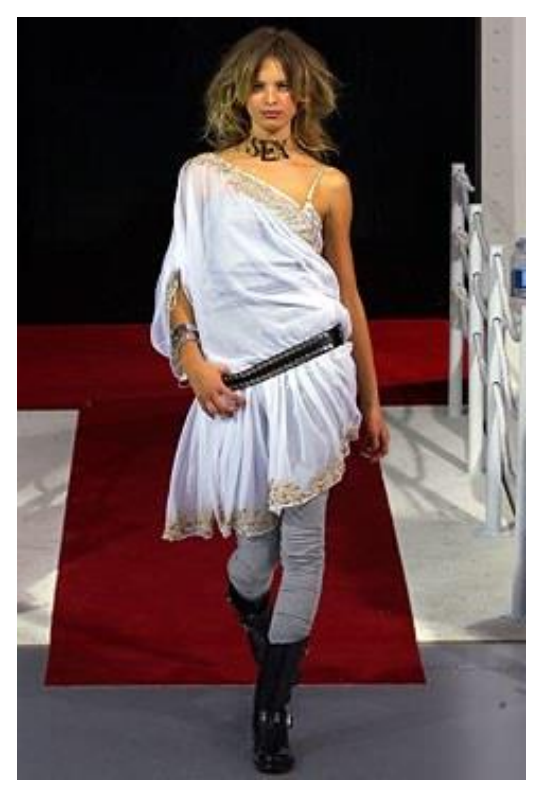

Рис. 9

У колекції Alexander McQueen весна/літо 2008 рр. давньоримську столу доповнено кітчевим сітчастим топом і яскравим рожевим паском (рис. 10). Кемповий підхід до інтерпретації античного костюм притаманний колекції Thomas Ford by Yves Saint-Laurent осінь/зима 2003-2004 pp., у якій давньогрецькі хітони поєднано із сітчастими колготами.

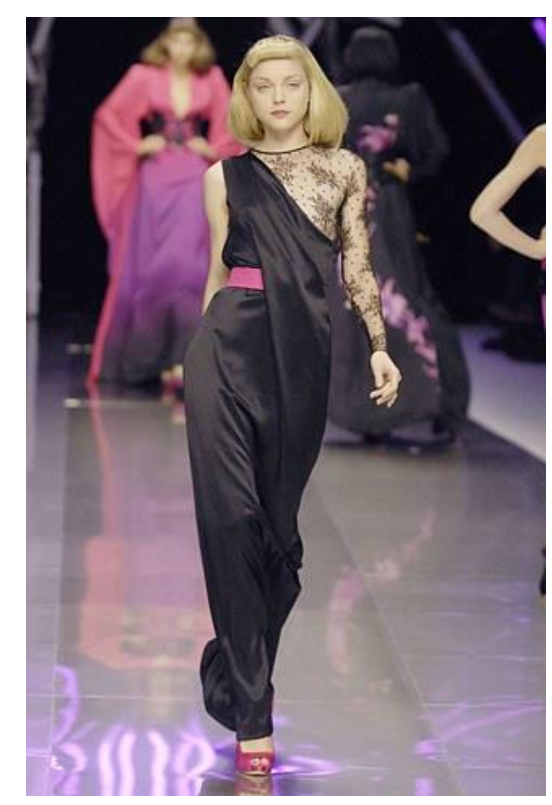

Рис. 10 
Значно більш частотними постмодерністська іронія та необарокове формовідчуття $\epsilon$ в інтерпретації суконь неокласицизму і стилю ампір. Прикладом слугує червоно-фіолетово-чорна шифонова шміз із колекції Christian Lacroix haute couture весна/літо 1991 р. з ліфом, декорованим золотим шитвом. Необарокова стилізація простежується в жовторожевій ампірній сукні з білими й бузковими стразами, увиразненій чорним болеро (Christian Lacroix, haute couture весна/літо 2005). Еклектичне поєднання ампірних форм і силуету з гіперболізованим рукавом-gigot 1880-х pp. зустрічаємо в сукні Christian Lacroix із колекції haute couture весна/літо 2005 р. У фіолетовій ампірній сукні з колекції Christian Lacroix haute couture осінь/зима 2007-2008 pp. драперіям надано динамічного, асиметричного ритму, а рукав-ліхтарик імітовано 3 клаптів мережив, хутра, тканин.

Зростання інтересу до античного естетичного ідеалу та одягової культури засвідчила тема щорічного балу Інституту костюма в ньюйоркському Метрополітен-музеї Met Gala 2003 - «Богиня: класичний образ». Подію супроводжувала виставка, перший розділ якої утворили інтерпретації античного костюма в сукнях та аксесуарах доби Директорії, Імперії, колекціях Paul Poiret, madame Gres, Madeleine Vionnet, Alexander McQueen, Thomas Ford, Nicolas Ghesquière. Другий моделі, безпосередньо інспіровані античними хітоном, пеплосом, гіматіоном, тунікою, тогою - від сьогодення до 1920-х рр. Третій елементи костюма, що дають змогу моделювати форми, зокрема поясні ремінці. У четвертому розділі на прикладі моделей Issey Miyake, Dolce\&Gabbana, Jean-Paul Gaultier, John Galliano розкрито сучасні технічні прийоми створення античних драпірувань. У п’ятому продемонстровано декоративні деталі й прикраси античного стилю, інтегровані в сучасний костюм. Дослідженню сучасних дизайнерських інтерпретацій античних мотивів присвячено книгу «Богиня: класична мода» (2003) Гарольда Кода.

\section{ВИСНОВКИ}

Отже, звернення до античних мотивів у колекціях 1980-2010-х рр. стало стадіально специфічним проявом наскрізної в моді й дизайні одягу тенденції до актуалізації античної одягової спадщини, іншими прикладами якої слугують неокласицизм Директорії, сукні стилю ампір, антикізуючі моделі Mariano Fortuny, Paul Poiret, Madeleine Vionnet, Madame Gres, Roy Halston.

Інтерпретація крою, форм, силуету, декору античного костюма в дизайні одягу 1980-2010-х рр. зумовлювалася дуальною природою постмодернізму з його «тугою за історією», естетичним ставленням до неї, інтересом до гуманістичного потенціалу традицій та ігровою, 
іронічною інтерпретацією культурних форм. У межах першого 3 означених спрямувань прагнення до поновлення гармонійної єдності людини i Космосу віддзеркалило в урівноваженості, виваженості пропорцій, наслідуванні крою, конструкцій, форм, силуету, декору античного костюма; довершеній простоті ліній і форм. Провідними модифікаціями аналізованого напряму стало створення тонко-ліричних образів античної гармонії на основі давньогрецьких (Gianfranco Ferre, Donna Caran, Alberta Feretti) і глорифікаційних - давньоримських одягових форм (Maria Grazia Chiuri, Pier Paolo Piccioli). Іронічно-ігровий характер постмодернізму відобразили значно менш численні в межах антикізуючого спрямування еклектичні поєднання елементів античного та сучасного костюма, деформація пропорцій, еротизація й кемповість образів (Gianni Versace, Dolce\&Gabbana, Alexander McQueen, Thomas Ford). Підпорядкування форм історичного костюма необароковій пластичній виразності зустрічаємо в опосередкованому сприйнятті античних впливів крізь призму костюма неокласицизму і стилю ампір (Christian Lacroix).

\section{АНОТАЦІЯ}

Статтю присвячено розкриттю образних, формотворчих, декоративних особливостей інтерпретації античних мотивів на грунті естетики постмодернізму в дизайні одягу 1980-2010-х рр. Продемонстровано, що звернення до античних мотивів у колекціях 1980-2010-х рр. є проявом наскрізної в моді й дизайні одягу актуалізації античних одягових традицій, більш ранніми прикладами якої слугують костюми Директорії, стилю ампір, антикізуючі моделі Mariano Fortuny, Paul Poiret, Madeleine Vionnet, Madame Gres, Roy Halston. Доведено, що інтерпретація крою, форм, силуету, декору античного костюма в дизайні одягу межі XX-XXI ст. зумовлювалася дуальною природою постмодернізму: його «тугою за історією» та іронічним потлумаченням культурних форм. Установлено, що перша 3 інтенцій віддзеркалила в урівноваженості, виваженості пропорцій, наслідуванні крою, конструкціям, силуету, декору античного костюма; довершеній простоті ліній - пластичних аналогах єдності людини i Космосу. Виявлено, що провідними модифікаціями аналізованого спрямування стали створення ліричних образів античної гармонії на основі давньогрецьких і глорифікаційних, піднесених - на основі давньоримських одягових форм. Аргументовано, що іронічно-ігровий характер постмодернізму зумовив еклектичне поєднання елементів античного й сучасного костюмів, деформацію пропорцій, еротизацію й кемповість образів (Gianni Versace, Dolce\&Gabbana, Alexander McQueen, Thomas Ford). Акцентовано на підпорядкуванні форм історичного античного костюма необароковій 
пластичній виразності та опосередкованому сприйнятті античних мотивів крізь призму костюма неокласицизму і стилю ампір (Christian Lacroix).

\section{ЛІТЕРАТУРА}

1. Білякович Л.М. Барокова стилістика французького костюма як парадигма європейської моди XVII-XVIII ст. Українська культура : минуле, сучасне, иляхи розвитку : збірник наукових праць ; Наукові записки Рівненського державного гуманітарного університету : у 2 т. / гол. ред. канд. пед. наук, проф. В. Г. Виткалов. Вип. 16. Рівне : Рівненський державний гуманітарний університет, 2010. T. II. C. 13-16.

2. Білякович Л. Вплив західноєвропейських барокових тенденцій на формування української моди XVII-XVIII століття. Українське мистецтвознавство : матеріали, дослідження, рецензіі : збірник наукових праць / гол. ред. акад. НАН України, докт. іст. наук, проф. Г. Скрипник. Вип. 9. Київ : ІМФЕ ім. М.Т. Рильського НАН України, 2008. С. 286-293.

3. Білякович Л.М. Класичні та сучасні наукові теорії художнього стилю бароко. Українська культура XXI cm.: стан, проблеми, тенденції : матеріали Всеукраїнської науково-теоретичної конференції (м. Київ, 22 грудня 2010 року). Київ : Видавничий центр КНУКіМ, 2010. Ч. І. С. 7-10.

4. Білякович Л.М., Воронцова О.М. Мода епохи італійського Відродження : морфологічні особливості костюма. VII Культурологічні читання пам'яті Володимира Подкопаєва. Культурна трансформація сучасного украӥнського суспільства : збірник матеріалів Всеукраїнської наук.-практ. конф., Київ, 4-5 червня 2009 р. Київ : ДАКККіМ, 2009. Ч. 1. C. $98-105$.

5. Білякович Л.М., Воронцова О.М. Морфологічні особливості костюма італійського Відродження. Вісник Державної академії керівних кадрів культури $і$ мистецтва : щоквартальний науковий журнал / гол. ред. докт. мист., проф. В.Д. Шульгіна. 2009. № 4. Київ : Державна академія керівних кадрів культури і мистецтва, 2009. С. 84-88.

6. Білякович Л. Темпоральність у структурі модних трендів: сутність, динаміка, прогнозування. Вісник Львівської національної академії мистецтв. Львів : Львівська національна академія мистецтв, 2018. Вип. 36. С. 207-222.

7. Білякович Л.М., Бондаренко І.В. Чинники формування костюма Київської Русі. Вісник Київського національного університету культури $i$ мистеитва : збірник наукових праць / гол. ред. кол. доктор пед. наук, проф. М.М. Поплавський, зам. голови ред. кол. доктор філос. наук проф. 
С.Д. Безклубенко. Київ : Київський національний університет культури і мистецтва, 2009. Вип. 20. С. 7-24.

8. Бушуева С.С. Классические мотивы в моде XX-XXI веков. Техникотехнологические проблемы сервиса / гл. ред. д. т. н., проф. Г.В. Лепеш. Вып. 1. Санкт-Петербург, 2013. С. 121-126.

9. Ванькович С.М. Прообразы современной моды в аспекте общехудожественных тенденций прошлых епох. Мода и дизайн: исторический опыт новые технологии : спец. вып. Вестника СПГУТД. Санкт-Петербург : СПГУТД, 2004. С. 112-123.

10. Витрувий. Десять книг об архитектуре. Москва : КомКнига, 2005. Кн. 4. 122 c.

11. Воронцова О.М. Італійський світський костюм XV-XVI ст. та його вплив на дизайн сучасного одягу : дис. ... канд. мистецтвознавства : 17.00.07 «Дизайн» / Київ. нац. ун-т культури і мистецтв. Київ : КНУКіМ, 2014. 219 c.

12. Галудзіна-Горобець В.І. Естетичні пріоритети постмодернізму як чинник становлення історизму в дизайні одягу другої половини XX початку XXI ст. : історіографічний аспект. Вітчизняна наука на зламі епох: проблеми та перспективи розвитку : матеріали Всеукраїнської науково-практичної інтернет-конференції (20 вересня 2018 року, м. Переяслав-Хмельницький). 2018. Вип. 44. Переяслав-Хмельницький, 2018. С. 32-35.

13. Галудзіна-Горобець В.І. Історизм у дизайні одягу другої половини XX - початку XXI ст.: генеза, динаміка, стильові особливості : дис. ... канд. мистецтвознавства : 17.00 .07 «Дизайн». Київ : Київський національний університет культури і мистецтв, 2019. 242 с.

14. Галудзіна-Горобець В.І. Історизм у дизайні одягу другої половини XX - початку XXI ст.: теоретико-методологічний аспект. Вісник Львівської національної академї мистецтв. 2018. Вип. 38. Львів : Львівська національна академія мистецтв, 2018. С. 93-111.

15. Грантовська О.А. Еволюція античної стилістики в європейському одязі : автореф. дис. ... канд. мистецтвознавства : 26.00.01 «Теорія та історія культури» / Київський національний університет культури і мистецтв. Київ : КНКіМ, 2011.245 с.

16. Демшина А.Ю. Ретроспективизм в современной моде как симптом динамики образов. Труды Санкт-Петербургского гос. ин-та культуры / ред. колл. А.Ю. Русаков (отв. ред.), Т.В. Захарчук (зам. отв. ред.), Л.Н. Кен, М.К. Лопачева, И.А. Свирская, С.А. Владимирова (отв. секретар). Вып. 1. Санкт-Петербург : СПбГУКИ, 2013. С. 9-17.

17. Дианова В.М. Постмодернистская философия искусства : истоки и современность. Санкт-Петербург : Петрополис, 1999. 240 с. 
18. Зеллинг Ш. Мода. Век модельеров 1900-1999. Koln : Konemann, $1999.658 \mathrm{c}$.

19. Козлова Т. Стиль в костюме XX века. Москва : МГТУ им. А.И. Косыгина, 2003. 160 с.

20. Косарева Е.А. Мода. ХX век. Развитие модных форм костюма. Санкт-Петербург : Петербургский институт печати, 2006. 468 с.

21. Кротова Т.Ф. Класичний костюм в європейській моді XIX початку XXI століття: еволюція форм і художньо-стильові особливості : автореф. дис. ... докт. мистецтвознавства : 17.00 .06 «Декоративне i прикладне мистецтво» / Львівська національна академія мистецтв. Львів : ЛНАМ, 2015. $31 \mathrm{c}$.

22. Леонова К.І. Вплив естетики постмодернізму на художньо-стильові та пластично-образні особливості дизайну одягу початку XXI століття. Вісник ХДАДМ : збірник наукових праць / гол. ред. академік НАМ України, доктор мистецтвознавства, проф. В.Я. Даниленко. Харків : ХДАДМ, 2016. № 1. С. 38-44.

23. Летина Н.Н. Рубежи - специфический код массовой культуры. Kодьр массовой культуры: российский дискурс : коллективная монография / под науч. ред. Т.С. Злотниковой, Т.И. Ерохиной. Ярославль : РИО ЯГПУ 2015. С. 84-98.

24. Маньковская Н.Б. Эстетика постмодернизма. Санкт-Петербург : Алетейя, 2000. 347 с.

25. Мерцалова М.Н. Костюм разных времен и народов : в 4 т. Москва : Академия моды, 1993. Т. 1. 542 с.

26. Москвин А.Ю. Исторический крой в современном проектировании: от реминисценции до реконструкции. Фундаментальные и прикладные исследования: проблемы и результаты : сборник материалов IX международной научно-практической конференции (16 декабря 2013 г., Новосибирск) / гл. ред. проф. О.К. Арутюнян. Новосибирск : ЦРНС, 2013. C. $168-172$.

27. Москвин А.Ю. Проектирование мужской одежды на основе ретроспективного системного анализа конструктивных решений : дисс. ... канд. техн. наук : 17.00.06 «Техническая эстетика и дизайн» / Санкт-Петербургский государственный университет технологии и дизайна. Санкт-Петербург : СПбГУТД, 2015. 239 с.

28. Москвин А.Ю. Ретроспективный анализ проявления исторических мотивов в модной форме костюма. Мир науки, культуры, образования / гл. ред. докт. пед. наук, проф. А.В. Петров. Горно-Алтайск : АтпГУ, 2014. № 2. C. 271-274.

29. Москвин А.Ю. Элементы исторического кроя в современном художественном проектировании. Вестник молодых ученых СанктПетербургского государственного университета технологии и дизайна : 
в 3 вып. / С.-Петербургск. гос. ун-т технологии и дизайна ; гл. ред. проф. А.Г. Макаров. Санкт-Петербург : ФГБОУВПО «СПГУТД», 2012. Вып. 3 : Искусствоведение и дизайн. С. 62-65.

30. Наседкина Ю.В. Основные категории эстетики постмодернизма и их воплощение в современной моде. Мода в контексте культуры : сборник статей Четвёртой науч.-практ. конф. (21 апреля 2009 г., СанктПетербург) / под общ. ред. Г.Н. Габриэль. Вып. 4. Санкт-Петербург : Изд-во СПбГУКИ, 2010. С. 81-87.

31. Чебан М. М. Античні мотиви в сучасному чоловічому одязі. Стан та перспективи розвитку культурологічної науки в Украйні : зб. тез доповідей III Всеукр. наук.-практ. конф. / редкол. Н. В. Федотова (гол. ред.) та ін. Миколаїв : МФ КНУКіМ, 2017. Ч. 2. С. 124-127.

32. Шевнюк О.Л. Історія костюма : навчальний посібник. Київ : Знання, 2008. 375 c.

33. Alberta Feretti. Spring. Ready-to-wear. 2008. URL: https:// www.vogue.com/fashion-shows/spring-2008-ready-to-wear/alberta-ferretti.

34. Christian Dior by Ferré haute couture spring summer 1992. URL: https://www.youtube.com/watch?v=_LcKDPh7LcY.

35. Donna Karan. SPRING 2002 READY-TO-WEAR. URL: https://www.vogue.com/fashion-shows/spring-2002-ready-to-wear/donna-karan.

36. Yves Saint Laurent by Tom Ford Fall/Winter 2003/04 Full Show / EXCLUSIVE. URL: https://www.youtube.com/watch?v=CYPmzp3h5uI.

37. Phelps N. Valentino. Fall 2015. Couture. VOGUE. JULY 9, 2015. URL: https://www.vogue.com/fashion-shows/fall-2015-couture/valentino.

\section{Information about authors:} Biliakovych L. M., Candidate of Technical Sciences, Professor at the Faculty of Design Borys Grinchenko Kyiv University 18/2, Bulvarno-Kudriavska str., Kyiv, 04053, Ukraine 